\title{
New evidence on the geologic setting of Medjerda Valley plain (northern Tunisia) from integrated geophysical study of Triassic evaporite bodies
}

\author{
Amira Ayed-Khaled ${ }^{1,{ }^{\star}}$, Taher Zouaghi ${ }^{2,3}$, Mohamed Atawa ${ }^{3,4}$, Mohamed Ghanmi $^{1}$ \\ ${ }^{1}$ Université Tunis El Manar, Département de Géologie, Tunis, Tunisia \\ ${ }^{2}$ King Abdulaziz University (KAU), Faculty of Earth Sciences, Jeddah, Saudi Arabia \\ ${ }^{3}$ Laboratoire de Géoressources, CERTE, Pôle Technologique de Borj Cédria, Soliman, Tunisia \\ ${ }^{4}$ Université de Carthage, Département des Sciences de la Terre, Jarzouna, Tunisia
}

\section{Article history}

Received April 28, 2014; accepted May 25, 2015.

Subject classification:

Tunisia, Atlas Mountains, Lineaments, Structuring, Triassic, Evaporites, Gravity modelling.

\begin{abstract}
Integrated gravity, two dimensional (2D) seismic and field data (lithostratigraphy and tectonic deformations) help to understand the structural setting of the Triassic evaporites in the Atlas Mountains of northern Tunisia. In the Medjerda Valley plain, Triassic outcrops are bounded by NE-, ENE-, and NW-trending faults. These faults have been reactivated and have controlled the basin framework. The gravity analysis included the construction of a gravity anomaly maps, and $2 \mathrm{D}$ gravity model. Corresponding gravity responses of the complete Bouguer anomaly, the residual gravity anomaly, and upward continued maps reveal that the Triassic evaporites do not have a neat gravity signature. $2 D$ seismic profiles show rising structures of Triassic strata associated with Mesozoic and Cenozoic tectonic edifices. The seismic horizons, calibrated to outcrop and well data, reveal paleohighs and diapirs of Triassic strata that were existed during the Jurassic and Early Cretaceous. These structural features induced a lateral outpouring of evaporitic strata within Late Cretaceous strata. A NW-SE-trending gravity model, which crosses the Medjerda Valley plain, highlights geometry identified on seismic lines. In the Medjerda plain, Mesozoic extensional and transtensional movements were associated with rising of Triassic evaporites, thus resulting in diapiric structures. The Late Cretaceous-Eocene structural setting was marked by outpouring of locally extruded Triassic evaporites. The Tertiary and Quaternary times are marked by major contractional events, causing inversion of pre-existing tectonic edifices. This integrated geophysical study provides a greater understanding of the Thibar deep structure, and a new geometry model of the Triassic evaporite bodies in the North Tunisia.
\end{abstract}

\section{Introduction}

The Atlas Mountains of northern Tunisia are characterized by numerous NE-trending outcrops of Triassic evaporites that are bordered by Cretaceous and Cenozoic strata. The Cenozoic strata are preserved in basins that trend generally NW, whereas the major structures (synclines and anticlines) trend generally NE [e.g., Ben Ayed 1993, Chihi and Philip 1998, Abbès 2004, Melki et al. 2010, Melki et al. 2011, Zouaghi et al. 2011]. Some authors have explained the formation of Triassic evaporite outcrops by a "diapiric" ascensional mechanism [e.g., Perthuisot 1978, Hammami 1999, Chikhaoui 2002, El Ouardi 2002, Ben Assi et al. 2006, Hamdi-Nasr et al. 2009], whereas others consider the Triassic evaporite outcrops as "salt glaciers" interbedded within the Cretaceous strata [e.g., Vila et al. 1994, Vila 1995, Ghanmi et al. 2000, Ghanmi et al. 2001]. Zouaghi et al. [2013] show that interaction of normal faulting and evaporite diapirism caused lateral outpouring of surface-piercing evaporites in the Sbiba graben in central Tunisia. Several autochthonous Triassic evaporites and associated fault escarpments have induced salt canopy structures [Zouaghi et al. 2013]. The aim of this study is to constrain the structural setting of Triassic evaporites in the Medjerda Valley-Thibar area of northern Tunisia (Figure 1), based on gravity, two dimensional (2D) seismic, and well data. In addition, the interpretation and correlation of seismic facies are used to delineate Jurassic to Quaternary seismic stratigraphic intervals, bounded by unconformities identified by downlap, onlap, and toplap discontinuities. Several previous studies have shown that northern Tunisia has undergone successive tectonic episodes. The Middle to Late Triassic deposits, described in the northern Atlas of Tunisia and particularly at the Triassic diapir zone, fossilized an extensional event related to the Tethyan rifting [e.g., Perthuisot 1978, Turki 1985, Adil 1993, 

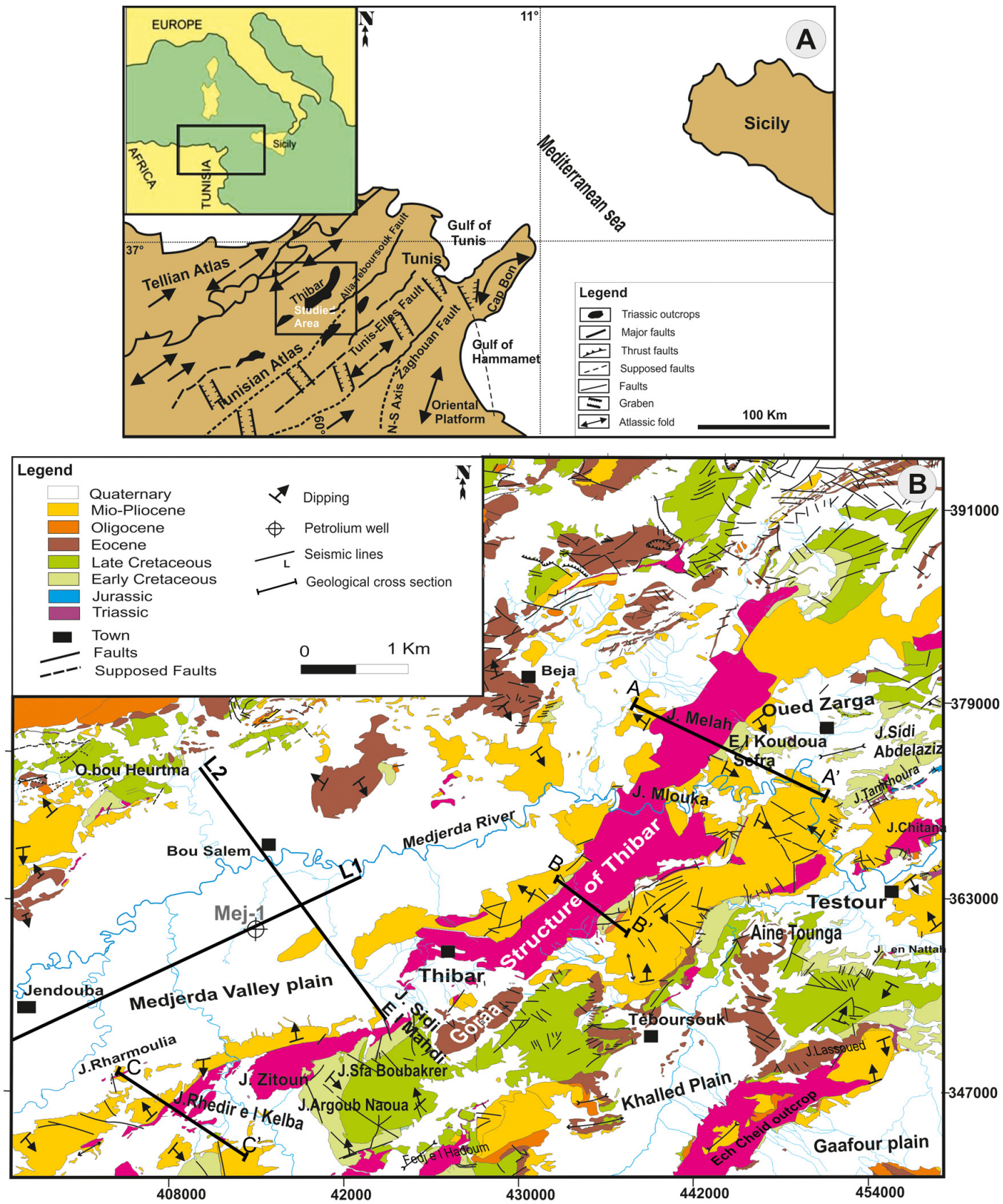

Figure 1. (A) Location of the Thibar area in the Atlas Mountains of northern Tunisia. (B) Geological map of the study area, extracted from 1/50,000 geological maps of Beja [Beily et al. 1982], Oued Zarga [Banjanik and Beily et al. 1985], Teboursouk [Perthuisot 1978], Jendouba [Ben Hadj Ali et al. 1994] and Bou Salem [Rouvier 1995]. This map shows the position of the Mej-1petroleum well and seismic lines (L1 and L2) used in this study.

Chikhaoui 2002, Soussi 2003]. The rifting was continued during the Jurassic and Early Cretaceous, inducing genesis of synclines, grabens and half-grabens separated by horsts [e.g., Boukadi 1994, Ghanmi et al. 2000, Bédir et al. 2001, Melki et al. 2010]. During this period, the El Alia-Teboursouk, Tunis-Ellès, and Zaghouan master faults (Figure 1A) controlled the distribution of sedimentation [e.g., Jauzein 1967, Zargouni 1977, Perthuisot 1978, Turki 1985, Hammami 1999, Chikhaoui 2002, Ben Chelbi et al. 2006]. Compressional tectonic episodes, which occurred during the Late Maastrichtian, the Middle and Late Eocene (Lutetian- Priabonian), the Miocene (Tortonian and Langhian-Serravalian), and Late Pliocene to Quaternary [e.g., Bouaziz et al. 2002,
El Euch et al. 2004, Zouaghi et al. 2005, Khomsi et al. 2006, Ould Bagga et al. 2006], have resulted in the formation of NE-trending folds with reverse faulting. These compressional events have been separated by long extensional events during the Oligocene to Early Miocene (Aquitanian) [e.g., Perthuisot 1978, Ben Ayed 1993] and the Late Miocene (Messinian) to Early Pliocene [Melki et al. 2010, 2011]. The major compression during the Miocene is considered to be part of the Alpine/ Atlasic Orogeny. In northern Tunisia, this compression formed NE-trending folds associated with NW-trending faults with oblique slip [e.g., Rouvier 1977, Zargouni 1977, Turki 1985, Ben Ayed 1993, Boukadi and Bédir 1996, Bouaziz et al. 2002, Zouaghi et al. 2005, 
Mzali and Zouari 2006, Melki et al. 2010, Melki et al. 2011, Zouaghi et al. 2011]. Other studies in northern Tunisia have highlighted the role of NE-SW, N-S, and NW-SE trending faults that were active during the Miocene [e.g., Burrolet 1956, Jauzein 1967, Ben Ayed 1993, Dlala 1995, Chihi and Philip 1998, Ghanmi et al. 2001, Bouaziz et al. 2002, Abdessalem Gharbi et al. 2005, Ben Mehrez et al. 2009, Amiri et al. 2011, Melki et al. 2010, Zouaghi et al. 2011]. The Late Permian-Early to Middle Triassic period of deformation was contemporaneous with the breakup of Pangea, characterized through a general NE-SW rifting. During the Jurassic, a N-S to NNW-SSE strong extension caused the dislocation of the initial continental platform and development of horsts and grabens, associated with subsiding basins [e.g., Turki 1985, Ben Ayed 1993, Bédir et al. 1996, Ghanmi et al. 2001, Bouaziz et al. 2002, Soussi 2003]. After a short Cretaceous (Aptian-Early Albian) transpressional period, NE-SW to ENE-WSW trending extensional events were marked during the Late Cretaceous, in relation with the general tectonic evolution of the northeastern African plate [e.g., Ben Ayed 1993, Ghanmi et al. 2001, Bouaziz et al. 2002, Ben Slama et al. 2009, Melki et al. 2010]. This period was accompanied by the intensive halokinetic and magmatic activities [e.g., Laaridhi-Ouazaâ 1994, Boukadi and Bédir 1996, Zouaghi et al. 2005]. During Cenomanian times, a second extensional event with ENE-WSW extension continued in the study area and has induced Triassic extrusion. [e.g., Zargouni 1977, Ben Ayed 1993, Boukadi 1994, Bédir et al. 1996, Hammami 1999, Ghanmi et al. 2001, Bouaziz et al. 2002, El Ouardi 2002, El Euch et al. 2004]. The Late Cretaceous extensions evidenced in Tunisia are characterized by a main near NE-SW component and affected the whole northeastern African margin, originating NW-SE to NNW-SSE striking basins [e.g., Chikhaoui et al. 1998, Bouaziz et al. 2002, El Euch et al. 2004]. North eastward, this extension extended only to northeastern Algeria [Bracène and Frizon de Lamotte 2002], whereas it was not reported farther west in the Maghreb. From Cenomanian to Early Maastrichtian times, the tectonic evolution in Tunisia was characterized by the same regional NESW extension known eastward in the whole northeastern African plate. Tectonic inversions, in Tunisia, was started at Late Maastrichtian-Paleocene, which constitutes a first compressional event probably in relation with the beginning of the Africa-Eurasia convergence [e.g., Zargouni 1977, Ben Ayed 1993, Boukadi and Bédir 1996, Guiraud 1998, Frizon de Lamotte et al. 2009, Aridhi et al. 2011, Zouaghi et al. 2011]. These compressional tectonic events were continued to Late Eocene [e.g., Perthuisot 1978, Turki 1985, Masrouhi et al. 2008] were considered as the major phases of the installation of the halokinetic structures. The complete inversion of the northwestern African continental margin was developed during the Miocene in relation with a NW-SE compression achieved in Tunisia at the Late Miocene Tortonian Atlasic phase [Rouvier 1977]. These compressional phases with NW-SE directions of shortening are responsible for the folding of the Cretaceous and Paleocene series. The N120E faults were reactivated in dextral strike-slip, and the N45E faults were still activated as reverse faults.

\section{Geological setting}

\subsection{Lithostratigraphy}

The Medjerda Valley-Thibar area is located in the "zone des dômes" dominated by NE-trending Triassic outcrops [e.g., Burrolet 1956, Zargouni 1977, Perthuisot 1978, Ben Ayed 1993, Vila 1995, Chikhaoui et al. 1998]. In this area, Triassic outcrops are located on the southeastern side of the Medjerda Valley and on the southeastern side of the Khalled plain and are recognized in the Mej-1 well (Figure 1B). The Triassic strata are generally consist of chaotic rocks including evaporites with thin beds of clay, sand, and dolostone with some metasomatized basalt sills and dikes [e.g., Adil 1993, Kammoun et al. 2001, Bouaziz et al. 2002]. The Jurassic strata, which outcrop at Jebel Sidi Abdelaziz, Jebel Tamrhoura, and Jebel Ahmar, consist of spotted limestone and marl that are overlain by Lower Cretaceous black marl and limestone interbedded with sandstone [e.g., Bajanik and Salaj 1970, Bouaziz et al. 1999, Bracène and Frizon de Lamotte 2002, Soussi 2003]. The black marl and limestone are overlain by Upper Cretaceous marl and limestone, which are overlain by Paleocene marls, followed by Eocene nummulitic limestones and Oligocene sandy strata [e.g., Chikhaoui 2002, Masrouhi et al. 2008, Ben Mehrez et al. 2009]. The Oligocene strata are overlain by thick Miocene marl, shale and sandstone, followed by Pliocene conglomerate and Pliocene to Quaternary sandy clay [e.g., Solignac 1927, Perthuisot 1978, Daly 1981, Chihi and Philip 1998].

\subsection{Tectonic setting}

The study area is subdivided into distinct domains bounded by structural lineaments and major faults (Figure 2). One important fault recognized in the study zone is NE trending El Alia- Teboursouk master fault (Figure 1). Thickness and facies variations of Cretaceous to Miocene strata (Figure 3) highlight the major effects of this fault during this time [e.g., Bouaziz et al. 2002, Khomsi et al. 2006, Masrouhi et al. 2008, Frizon de Lamotte et al. 2009, Melki et al. 2010, Aridhi et al. 


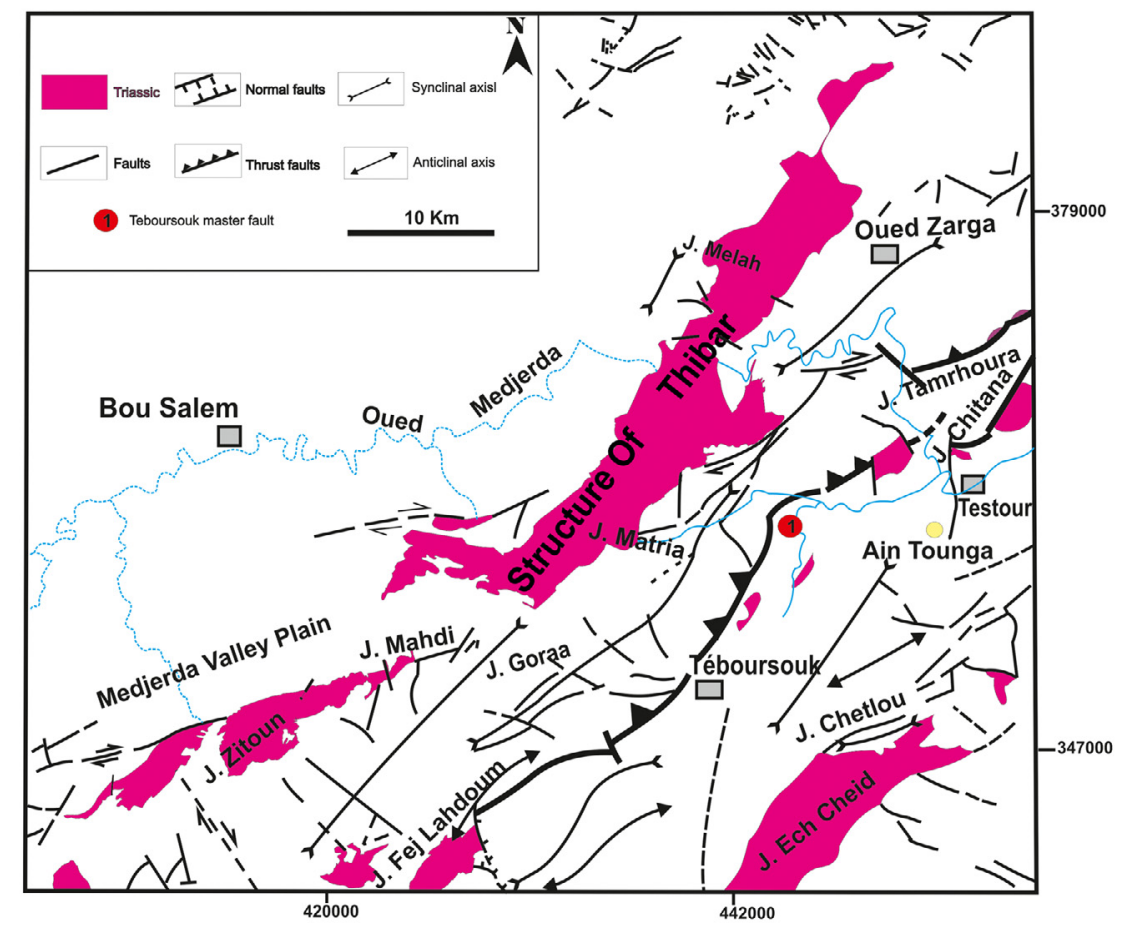

Figure 2. Structural map of the Thibar area at northern Tunisia, showing location of the main outcropping tectonic features (after Ben Ayed [1986], modified).

2011, Melki et al. 2011]. In addition, distribution and structuring of Upper Cretaceous strata (CenomanianEarly Campanian) highlight structural differentiation into high and low domains with tilted blocks. Within the study area, Triassic evaporites have tectonic contact with Cretaceous strata at several locations, such as Jebel Melah, Jebel El Koudoua Safra, and Jebel Matria (Figure 1B). On the northwestern side of Jebel Melah, a NW-trending basin contains NW-dipping Miocene strata that have tectonic contact with Triassic evaporates (Figure 4, Section AA'). These Miocene strata are capped by unconformities, above which lie Pliocene strata. However, on the southeastern side of Jebel Melah, the same Triassic evaporites have tectonic contact with SE-dipping Lower Cretaceous (BarremianAptian) marly limestones capped by an unconformity, above which lie Pliocene strata. At Jebel El Koudoua Safra (south of Jebel Melah), Cretaceous (Aptian) carbonate beds are affected by several minor faults sealed by Cretaceous (Albian) clay. These N30E-N40E trending normal minor faults reveal an extensional tectonic phase that induced the tilting of blocks during the Albian. Moreover, previous authors have proposed the initiation of halokinesis in the Atlas Mountains during this period [e.g., Jauzein 1967, Zargouni 1977, Adil 1993, Vila et al. 1994, El Ouardi and Turki 1995, Ghanmi et al. 2001, Ben Slama et al. 2009]. At the Jebel Matria area unconformity is marked by a direct contact of Triassic evaporites with Cretaceous (Aptian) strata (Figure 4, Section $\mathrm{BB}^{\prime}$ ). The Aptian strata are overlain by Albian to Paleocene strata, all of which dip towards the north- west. Marls of the Paleocene El Haria Formation are capped by an unconformity (Figure 3). In the Jebel Rhédir El Kelba area (Figure 4, Section CC'), that constitutes the southern part of the Thibar structure, Triassic anticline structures are separated by synclines filled by Neogene deposits at the northwestern part of the section, and Cretaceous deposits of Goraa syncline at the southeastern part.

\section{Data and methods}

This study is based on the gravity processing and $2 \mathrm{D}$ seismic interpretation in order to establish 2D geometric model for the Triassic structures of the Medjerda Valley plain area. The gravity data were acquired by the Office National des Mines (ONM) of Tunisia with a grid of one station per $\mathrm{km}^{2}$. They were gridded at a spacing of $0.5 \mathrm{~km}$ using a minimum curvature technique [Briggs 1974] and contoured at a $1 \mathrm{mGal}$ interval to map the complete Bouguer gravity anomaly. The acquired data include the responses of deep structures and enable calculations of a residual gravity anomaly, which should be distinguished from a regional background gravity anomaly. The horizontal gradient techniques coupled with the upward continued maps [e.g., Everaerts and Mansy 2001, Khattach et al. 2004, Vanié et al. 2005, Ayed et al. 2006, Ayed-Khaled et al. 2012] show density contrasts and provide information allowing to delineate geological units [Cordell and Grauch 1982, Blakely and Simpson 1986]. The effects of high wave lengths were assessed from upward continued maps at altitudes of $3 \mathrm{~km}, 5 \mathrm{~km}, 10 \mathrm{~km}$, and $20 \mathrm{~km}$. The 


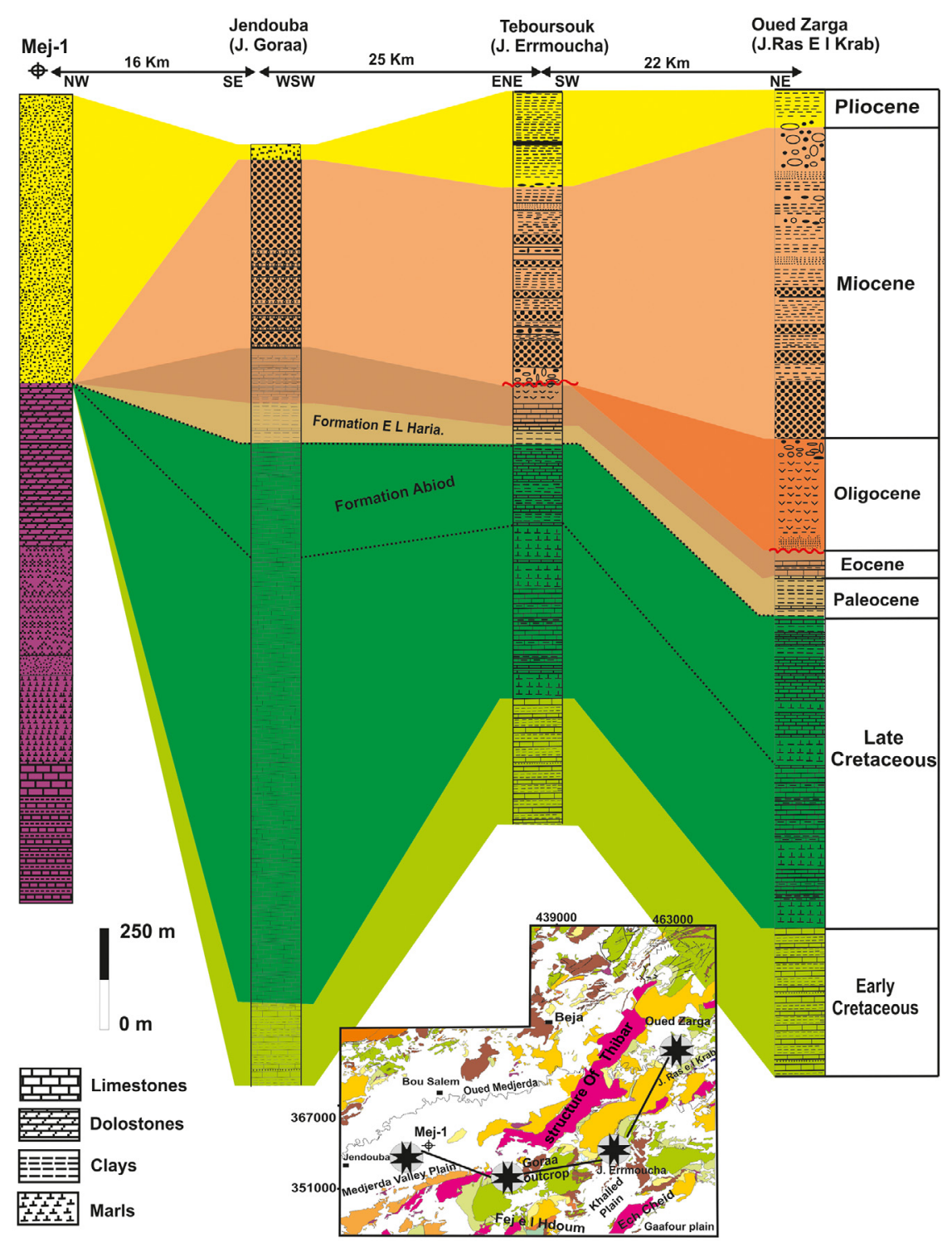

Figure 3. Lithostratigraphic correlation of the Mej-1 well and Mesozoic and Cenozoic outcropping strata, showing thickness and facies variations and subsidence inversions related to tectonic deformations in the Thibar area.

Triassic outcrop patterns were digitized using a $1 / 50,000$ scale map and superimposed on the contours of the complete Bouguer gravity map.

In order to accentuate the shallow source anomalies, a continuation filtering process was applied which is designed lead to a separation of long wavelength anomalies from short wavelength ones. In this study, the separation of regional and residual anomalies constitutes an essential part of potential field interpretation [Blakely 1996]. The present case study regional component [Blakely and Simpson 1986] was computed through upward continuing the Bouguer gravity grid to $20 \mathrm{~km}$. It is relevant to indicate that for higher continuation levels, the extracted map shape is almost unchanged. Thus, the residual gravity map was computed by subtracting the regional grid from the Bouguer gravity grid in order to enhance the short wavelength features that usually correspond to shallow elements of geology. In order to determine gravimetric lineaments, the map of maxima of horizontal gradient was established. The Euler Deconvolution was generated to determine the location and the depth of the sources. A quantitative approach of 2D modeling aims to deduce geometry of the Triassic bodies in the Medjerda plain.

The 2D seismic lines were acquired by Carthago Oil Company, and were donated to the authors by the ETAP petroleum company of Tunisia (Entreprise Tunisienne d'Activités Pétrolières). 2D-seismic profiles were calibrated using time-depth conversion of lithologic data from the Mej-1 petroleum well. This well was drilled at the western part of study area and it encountered Triassic evaporites beneath Pliocene and Quaternary strata in the Medjerda plain (Figure 1). The gravity and 2D seismic data were used to identify geological structures. Seismic horizons allowed the recognition of seismic stratigraphic units bounded by major unconformities 

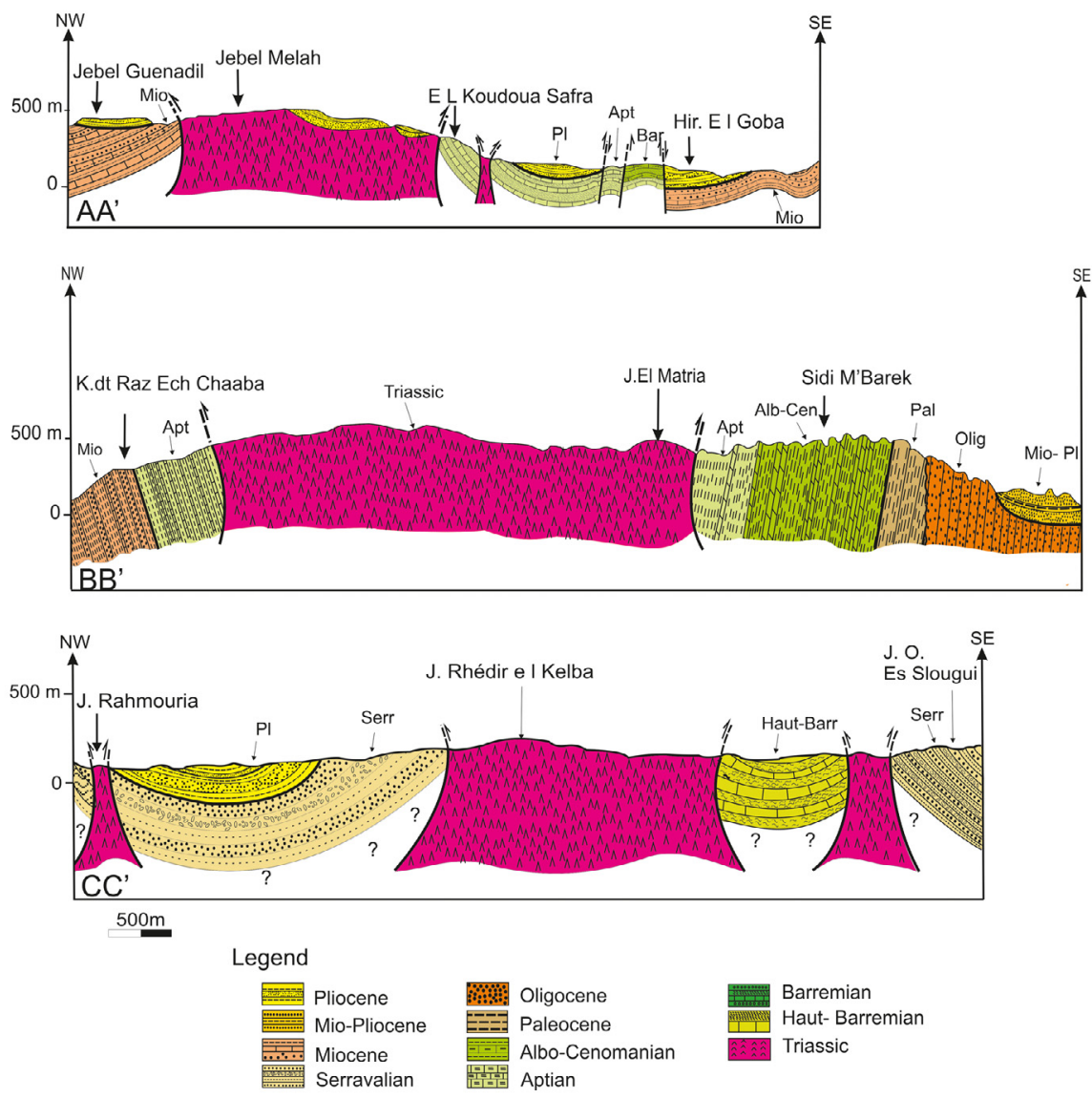

Figure 4. Structural outcropping sections at Jebel Melah (AA'), Jebel Matria (BB') and Jebel Rhédir El Kelba (CC') in the Thibar area of northern Tunisia. These sections show contacts of the Thibar Triassic evaporites with adjacent Mesozoic and Cenozoic strata (section locations are shown on Figure 1).

identified by downlap, onlap, and toplap surfaces.

The seismic study was completed by a quantitative approach of 2D gravity modelling, which is constrained to deduce geometry of the Triassic bodies in the Medjerda plain.

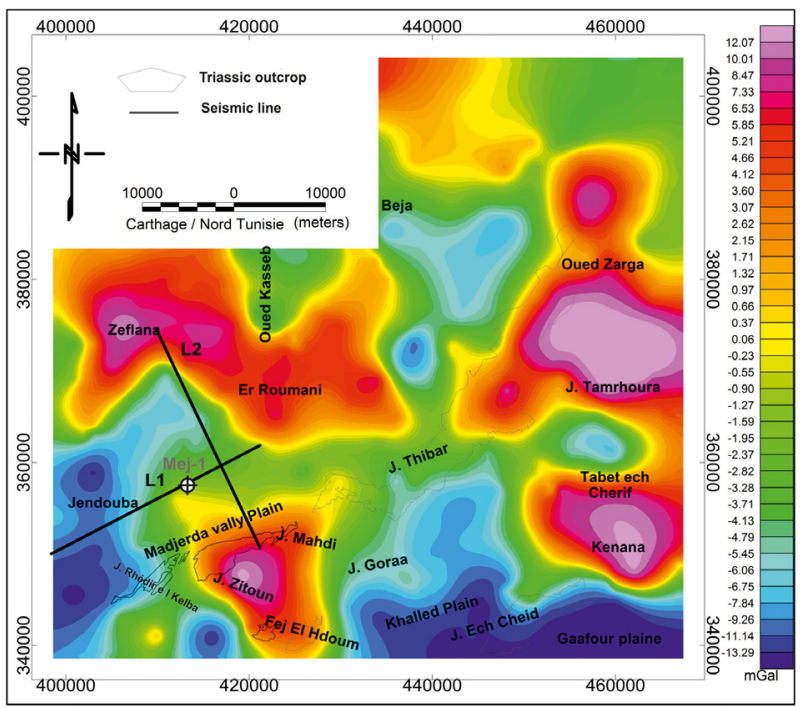

Figure 5. Complete Bouguer gravity anomaly map of the Thibar area (northern Tunisian Atlas).

\section{Gravity study}

The gravity data used in this study cover the 1/ 50,000 scale geological maps of Beja [Beily et al. 1982], Oued Zarga [Banjanik and Biely et al. 1985], Teboursouk [Perthuisot 1978], Jendouba [Ben Hadj Ali et al. 1994] and Bou Salem [Rouvier 1995]. Products derived from the gravity data include a complete Bouguer gravity anomaly map (Figure 5), a regional anomaly map (Figure 6), a residual gravity anomaly map (Figure 7), a map of maxima of the horizontal gravity gradient (Figure 8A) and Euler Deconvolution (Figure 8B). On the Bouguer gravity anomaly map (Figure 5), the isoanomaly curve varies from $-13.29 \mathrm{mGal}$ to the southest to $12.07 \mathrm{mGal}$ to the east and the west. Positive anomalies are located in the eastern, western and southern parts of the map. The most important anomaly is slightly to the east, and corresponds to Jurassic outcrops of Jebel Tamrhoura (Figure 5). At the southeast, a positive anomaly distinguishable by high amplitude coincides with Tabet Cherif syncline; at the southwest, a positive anomaly coincides with Triassic and Cretaceous outcrops of Jebel Zitoun-Jebel Mahdi (the southern part of the Thibar structure), Jebel Argoub Naoua, and Jebel Sfa Boubakrer (Figures 1B and 5). The maximum amplitude occurs over outcrops of Lower Cretaceous 

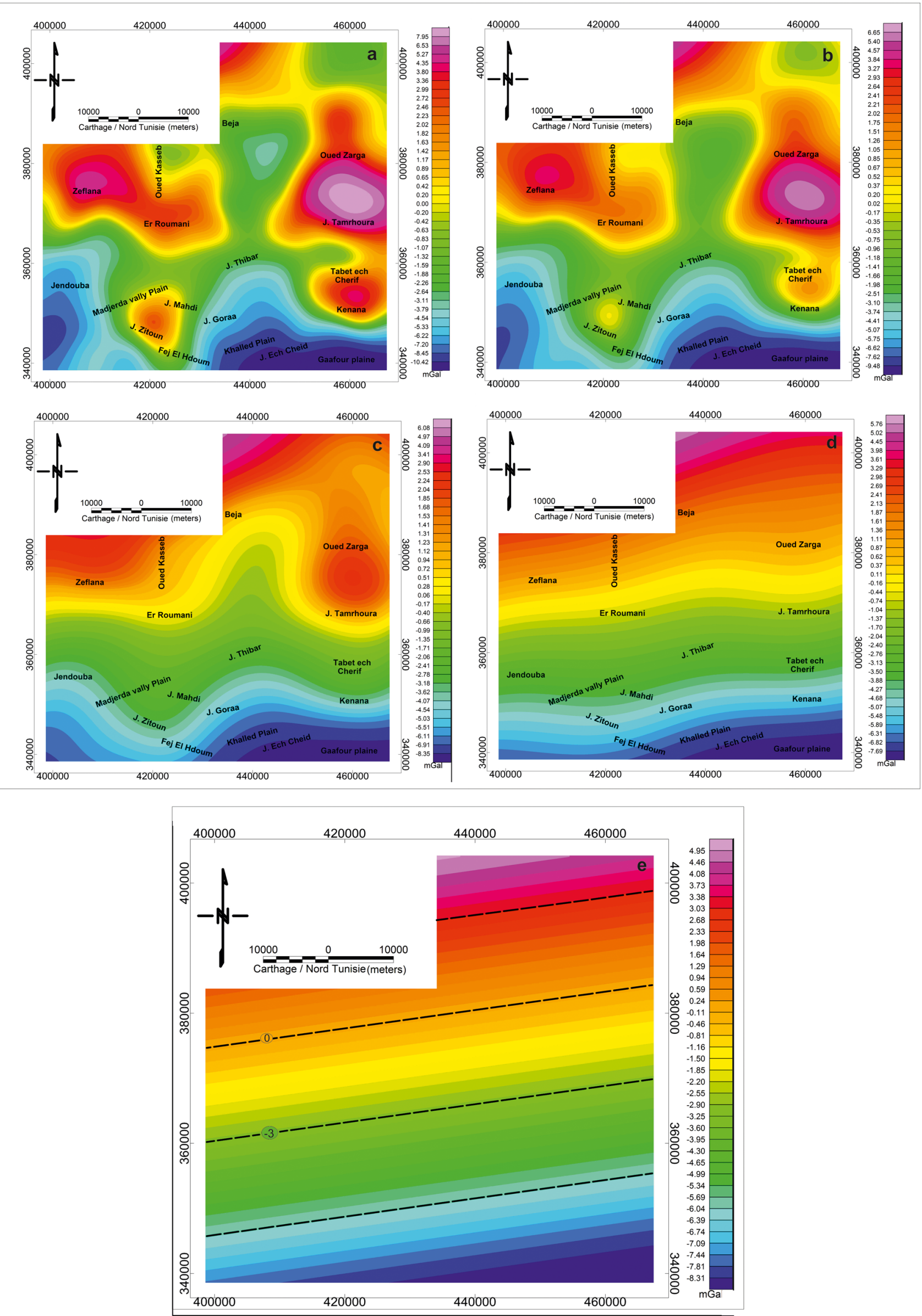

Figure 6. Upward continuation maps: (a) at $3000 \mathrm{~m}$; (b) at $5000 \mathrm{~m}$; (c) at 10,000 m; (d) at 20,000 m; (e) at 22,000 m (Regional anomaly map). 
limestone and marl, which are characterized by significantly high density values (Figure 5). Negative anomalies are located mainly at the south, corresponding to the Khalled plain and at the west, corresponding to the Medjerda plain (Figure 5). These negative anomalies indicate that all this area is covered by the unconsolidated Quaternary sediments of the Medjerda River (Figure 1B). The Bouguer gravity anomaly map highlights a variable response of the Triassic strata (Figure 5). The northern part of the Triassic outcrop at Thibar cannot be characterized by a particular signal (Figures 1B and 5), and it occupies a zone of transition between two fields of positive and negative amplitude. In contrast, the southern part expresses strong positive response at Jebel Zitoun, and a slightly negative response at Jebel Rhédir el Kelba (Figures 1B and 5). This variety of gravity responses can be explained by the influence of structures neighbouring of the Triassic outcrops.

The observed complete Bouguer anomalies present the effect of all density heterogeneities under the topographic surface. To determine deeper structures associated to Triassic bodies, we must remove the regional gravity anomaly that highlights the effect of deeper densities contrast. Thus, we use the decomposition of Bouguer anomalies on regional and residual anomalies, based on the upward continuation method that classifies the sources according to their depth; superficial and deep sources [Jacobsen 1987, Blakely 1996, Jacoby and Smildes 2009]. The regional anomalies of study zone are defined as the upward continued field to $20 \mathrm{~km}$ (Figure 6A). The gravity values decrease towards the SE (Figure 6B); these are certainly in relation with deep crustal structure.

The residual gravity anomaly map displays shorter

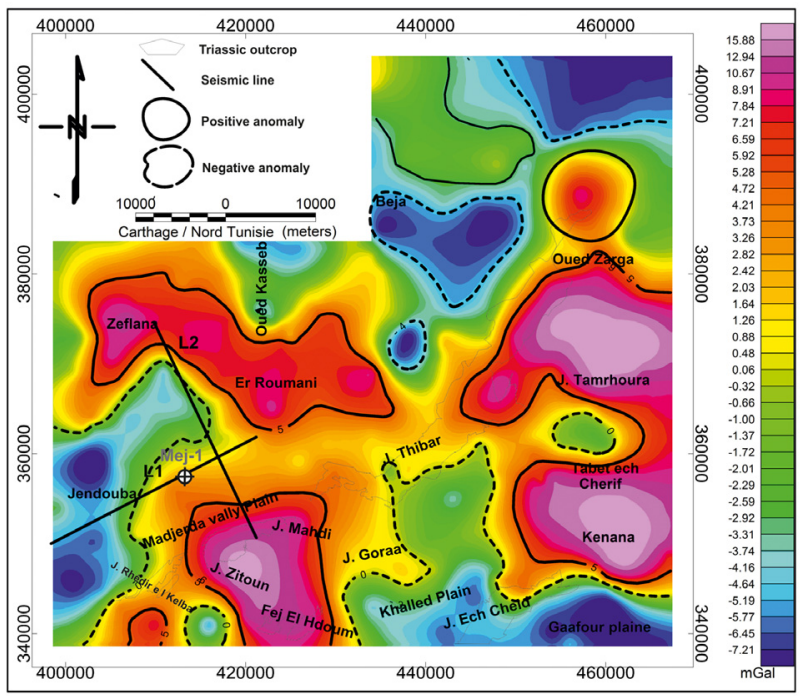

Figure 7. Residual gravity anomaly map of the Thibar area (northern Tunisian Atlas). wavelength anomalies with values ranging between -7.21 and $15.88 \mathrm{mGal}$ (Figure 7). The northern part of the Thibar structure occupies already a transition zone between positive and negative anomalies. High amplitude maxima are located in the eastern and southwestern parts of the map, and they occur over Jurassic deposits at Jebel Tamrhoura, over Triassic and Lower Cretaceous outcrops at Jebel Zitoun and Jebel Mahdi (Figure 7). In contrast, NE-trending curves indicate a gravity gradient decreasing laterally towards the northwestern and the southeastern parts of the study area, superimposed respectively on Neogene deposits and the Khalled and Gaafour plains (Figure 7).

Maxima of the horizontal gravity gradient reveals a variety of thin but stretched out alignments, the most significant of which is surrounding the Triassic outcrops (Figure 8A). Thus, there is tentative evidence that these maxima of the horizontal gravity gradient might reflect lateral density contrast between the Triassic evaporite strata and the surrounding rocks. In the maxima map of the horizontal gravity gradient, the major $\mathrm{NE}-$ and NW- trending features correspond to regional faults (Figure 8A). This map also shows NE- and NWtrending features that delimit the Thibar Triassic outcrop to NW and SE (Figure 8A).

Figure $8 \mathrm{~B}$ presents Euler solutions obtained for a structural index of 0.25 , a window size of $11 \times 11$ cells and tolerance of 10 . The colored dots show the source edges, and each color is in relation to one of the estimated depths which are spread out in eight ranges. In the Beja area, the solutions indicate the presence of deep geological structures. The eastern part of study area shows major E-W- trending features that delimit the region of Tamrhoura (Figure $8 \mathrm{~B}$ ). At the western part, the Medjerda valley domain is limited by an important and deep E-W and NW-SE fault system. In the other hand, the north part of Thibar Triassic structure highlights a NNW oriented aligned solution which expresses a fault system in the same direction (Figure 8B). In the southwestern part of the study area, a positive anomaly is bordered to the north by aligned solutions corresponding to the northern limit of the Triassic outcrop of Jebel Mahdi (Figure 8B). The Triassic body of Fej El Hdoum is limited by a NS fault system marked by the alignment of solutions (Figure 8B).

The cumulative lineament map (Figure $8 \mathrm{C}$ ) is obtained by superposition of lineaments that are evidenced by different Gravity component maps. This map reveals the existence of NE-SW and NW-SE major lineaments bordering the Triassic structures of Thibar-Jbel Mahdi- Jbel Zitoun. In the central-western part of the map, two NE-SW lineaments were detected and limited the Triassic outcrop of Jbel Rharmouria (Figure 8C). 

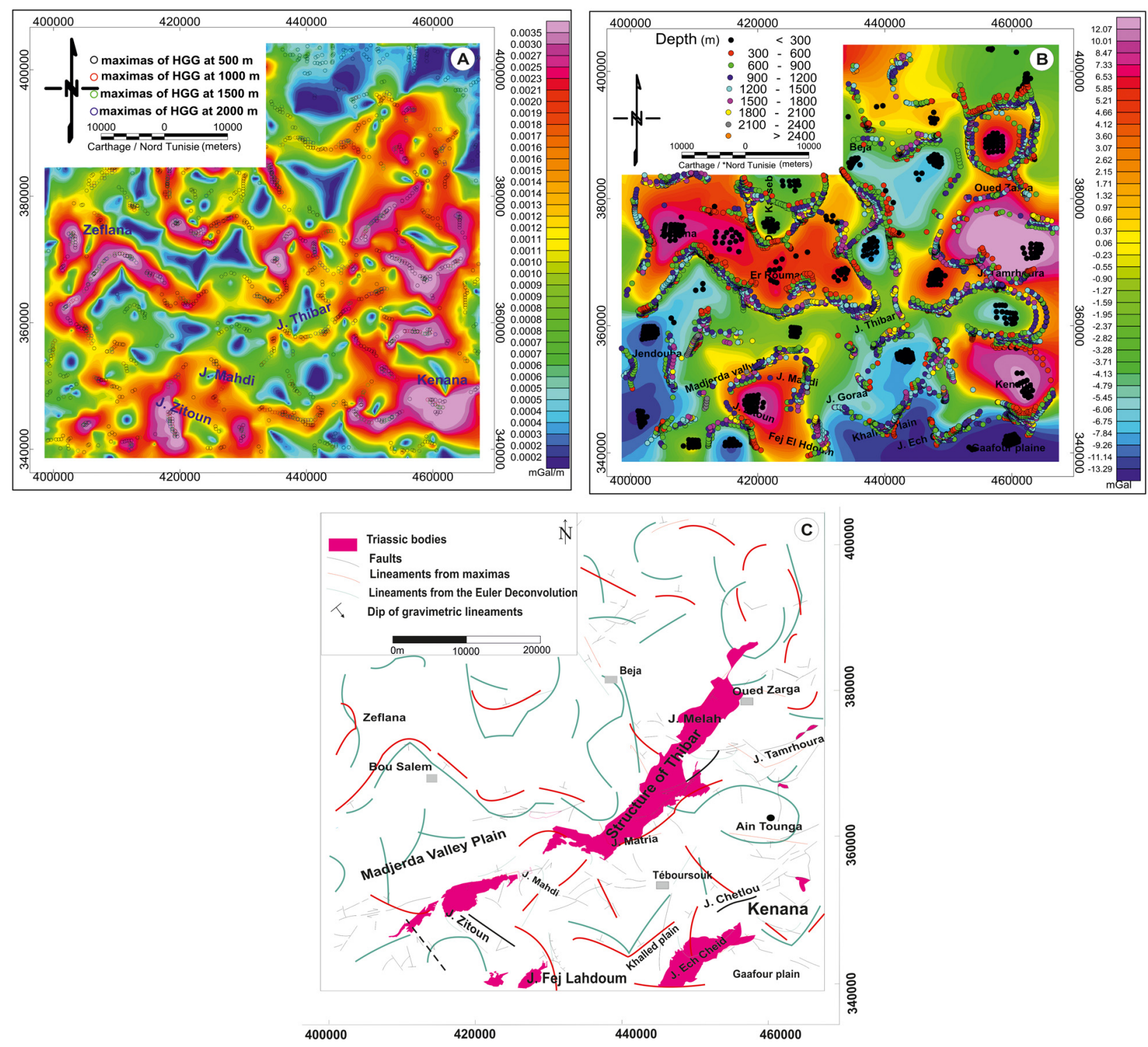

Figure 8. (A) Maxima of the horizontal gravity gradient map; (B) Euler deconvolution map superimposed on residual gravity map. The solutions were found using a structural index of 0.25 ; (C) Structural map showing lineaments deduced from gravity analysis.

To the southeastern part, a NS fault system limits the Triassic outcrop of Fej El Hdoum to the east. The frequent E-W, NW-SE and N-S direction has an important role in the geometry of the study zone (Figure $8 \mathrm{C}$ ). These faults limit the Bou Salem plain to the northwestern part of the map and Triassic structures in the south part.

\section{2D seismic analysis}

The seismic line L1 crosses the Medjerda Valley longitudinally from northeast to southwest (Figure 1B). Analysis of seismic reflection profile L1 shows asymmetric synclines and half-grabens that are bounded by uplifted structures and by cross-cutting faults trending NW (Figure 9). Variations of strata thicknesses are notable, and there is a stratigraphic gap between Triassic strata and overlying Jurassic, Cretaceous and Tertiary strata. On the western flank of the grabens, Upper Cre- taceous (Campanian-Maastrichtian) and PaleoceneEocene seismic reflectors structures are bounded by an angular unconformity on the uplifted flank to the west and on the salifereous outpouring to the east (Figure 9).

The seismic profile L2 crosses the Medjerda Valley transversally from northwest to southeast (Figure 1B). This seismic line shows the NE-trending folds and associated reverse faults. The NE-trending Jendouba fault (Figure 10), which borders the Medjerda Valley to the NW, displays reverse movement. The geometry of other major faults and folds also argue for reverse faulting, as well as folding by shortening (Figure 10). The borders of the depocenters are marked by a chaotic seismic facies, which correspond probably to Triassic evaporites (Figure 10).

On the two seismic lines (L1 and L2), the Neogene strata display great variation of seismic facies and wide hiatuses on the tops of paleohighs. The subsiding zones 


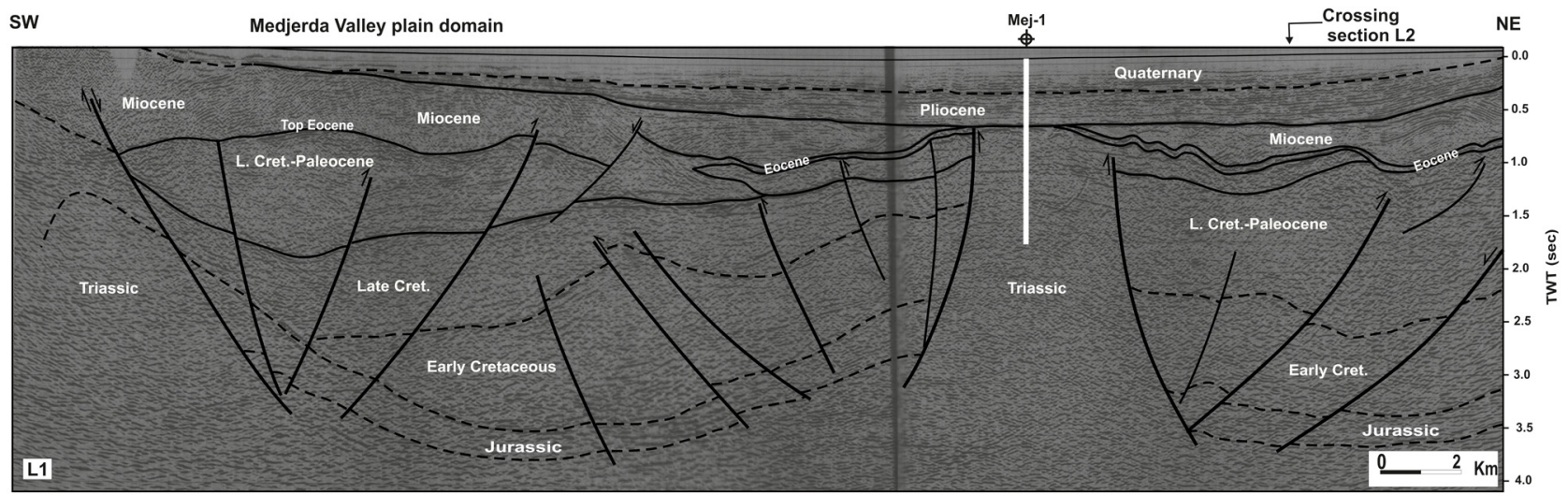

Figure 9. Interpreted seismic line L1 across the Medjerda Valley Plain (location shown in Figure 1), illustrating distribution of the Mesozoic and Cenozoic strata depositions and their relation with the NW-trending faults and associated Triassic evaporites.

show thick deposits that thin and pinch out laterally on the margins of the basins (Figures 9 and 10). The seismic lines L1 and L2 reveal a tectonic contact between the Triassic evaporates and the Jurassic and Cretaceous strata (Figures 9 and 10). Outcropping Jurassic strata show a thinning near Triassic diapiric structures [Bismuth et al. 1981]. The Early Cretaceous strata also show a reduction of thickness near the Triassic evaporites (Figure 9). In the depocenters, the Triassic evaporites have a contact with Jurassic, Early Cretaceous, Upper Cretaceous, Cenozoic, and Quaternary deposits. Correlation of seismic reflectors shows an Upper Cretaceous layer below the Triassic evaporites of the Medjerda Valley plain (Figure 9). The boundary between the Triassic evaporites and the Upper Cretaceous strata is marked by a change of the seismic facies. The Triassic deposits are represented by chaotic reflections. The seismic facies shows the allochtonous character of the Triassic deposits, few kilometres away from the high diapiric structure (Figures 9 and 10). The Triassic strata are concordant with the underlying Upper Cretaceous strata. Moreover, the geometry observed on the two seismic lines highlights a sedimentary instability ascribable to a pre-existent slope and a stratigraphic polarity on both sides of the Thibar and neighboring high structures (Figures 9 and 10). The subsurface data reveal that a blade of Triassic evaporites is overlain by an unconformity, above which lies Upper Cretaceous and Eocene strata.

\section{Gravity forward modelling}

While the seismic profiles have revealed the presence of $2 \mathrm{D}$ geometries of the Triassic evaporite structures at northern Tunisia, informations about their density, lithology and thickness is needed to establish an integrated geological model based on outcrop and geophysical data (Figure 11).

The GM-SIS software has been used for modelling of gravity data (Figure 11). In our case, interpretation of the observed gravity anomaly is constrained by geological observations (outcrops and well data) to determine lithologies and limits of the sedimentary layers. To constrain the model, the sedimentary strata were subdivided into different units based on their rock

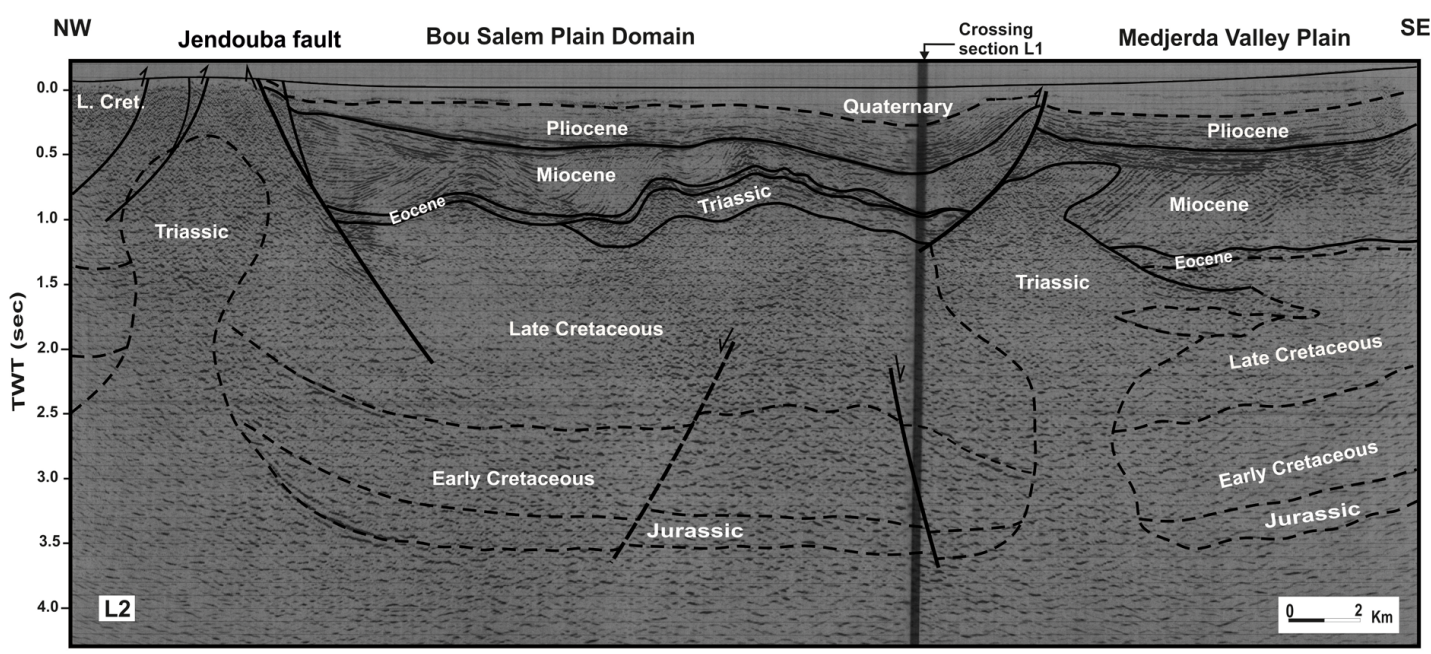

Figure 10. Interpreted seismic line L2 across the Medjerda Valley Plain (location shown in Figure 1), illustrating distribution of the Mesozoic and Cenozoic strata and their relation with the NE-trending faults, E-W faults, and associated Triassic evaporites. 
type (Figure 3). Average values of densities used in this study have been derived and estimated from published studies and from ONM (National office of Mines of Tunisia) (Table 1).

In the present study, the $2 \mathrm{D}$ gravity modelling along NW-SE seismic profile (L2) (Figure 11) highlights diapiric structures models with a lateral outpouring, emphasized at the center of the Medjerda Valley plain. To the NW part, a Triassic structure $\left(2.51 \mathrm{~g} / \mathrm{cm}^{3}\right)$ shows anomaly of $6 \mathrm{mGal}$ and to the SE part, the model indicate a diapiric Triassic structure with lateral outpouring and reveals anomaly (1 mGal to $6 \mathrm{mGal}$ ) (Figure 11). The average value of the density corresponds to the Triassic evaporites of northern Tunisia, which outcrops as extrusion structures of gypsum, clay, marl, dolomite and sandstone, with occasional fossiliferous carbonate levels. In this model, diapiric bodies were surrounded by thick layers of Cenozoic sediments; at depth, Triassic bodies are surrounded by the Jurassic dense series $\left(2.6 \mathrm{~g} / \mathrm{cm}^{3}\right)$ and Cretaceous $\left(2.32 \mathrm{~g} / \mathrm{cm}^{3}\right.$ for Early cretaceous series to $2.35 \mathrm{~g} / \mathrm{cm}^{3}$ for Late Cretaceous).

\section{Discussion}

Structural and stratigraphic observations carried out on seismic sections crossing the Medjerda Valley and surrounding areas show a diapiric original structure associated with lateral outpouring of Triassic evaporites, which could be related to the "salt glacier" mechanism. Several hiatuses near Triassic evaporite outcrops at the northern Atlas Mountains suggest that sediment accumulation and erosion were controlled by tectonic and halokinetic movement (Figures 9 and 10). The reactivation of the deep basement faults caused

\begin{tabular}{lc}
$\begin{array}{l}\text { Lithostratigraphic } \\
\text { series }\end{array}$ & $\begin{array}{l}\text { Density } \\
\left(\mathrm{g} / \mathrm{cm}^{3}\right)\end{array}$ \\
\hline Quaternary & 2.15 \\
Pliocene & 2.1 \\
Miocene & 2.35 \\
Eocene & 2.4 \\
Late Cretaceous & 2.35 \\
Early Cretaceous & 2.32 \\
Jurassic & 2.6 \\
Triassic & 2.51 \\
\hline
\end{tabular}

Table 1. Average density for different lithostratigraphic series in the Thibar area.

Triassic evaporite movement and rising along faulted border of basins from the Jurassic rifting. The thinning of Jurassic strata on the flanks of Triassic diapirs could indicate a pillow stage that was recorded at the central and southern Atlas of Tunisia by other authors [e.g., Chikhaoui et al. 1998, Hlaiem 1998, Hammami 1999, Bédir et al. 2001, Zouaghi et al. 2005, Melki et al. 2010, Zouaghi et al. 2013]. Halokinesis seems to have continued as domes and diapirs during the Cretaceous extensional tectonic events [e.g., Perthuisot 1978, El Ouardi and Turki 1995, Hammami 1999, Jallouli and Mickus 2000]. Strata show a reduction of thickness near the Triassic evaporates. The thickness reductions of the Jurassic deposits associated with onlap and toplap structures on the sides of the Triassic bodies, and the blades enclosed within the Upper Cretaceous series (Figure 10), lead us to deduce an old rising since the Jurassic periods (Figures 9 and 10). The geometry of the Thibar
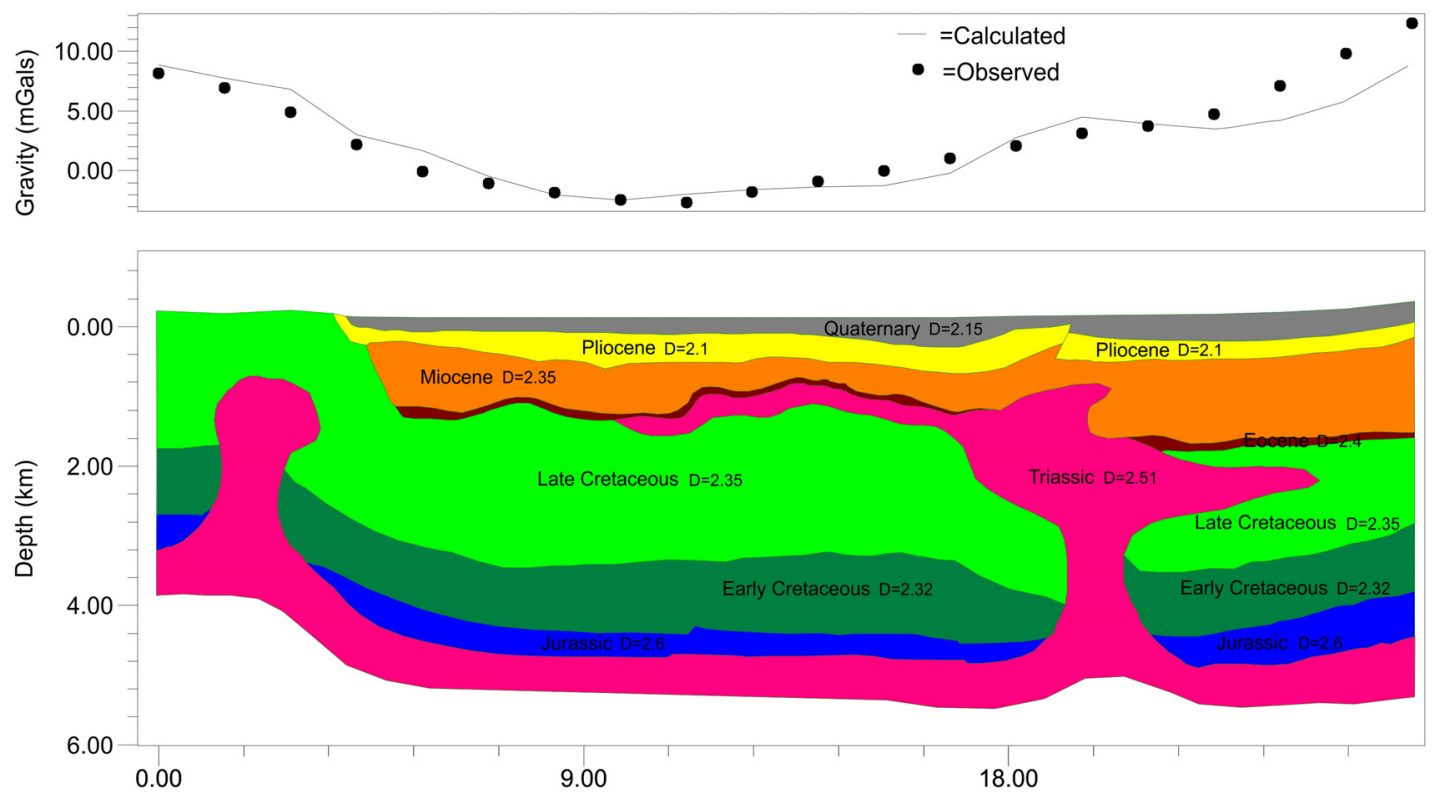

Figure 11. Two dimensional model (2D) along NW-SE section in the Medjerda Valley Plain, showing a diapir Triassic structure with lateral outpouring at the center of the basin. 
"salt glacier" structure and their sedimentary contacts far from the main diapiric source, could be related to their underwater spreading out at the Late Cretaceous (Figures 9 and 10). This extensional period seems to have induced subsidence, as shown by thickness changes within depocenters and locally accompanied by volcanic extrusions. The Late Eocene tectonic event is expressed on the studied seismic lines by a clear discordance of Eocene series on the Late Cretaceous (Abiod Formation) (Figure 10). This shortening phase generated the Atlasic structures, among them the Thibar diapiric anticline. Based on the classifications proposed by several studies [e.g., Wu et al. 1990, Diegel et al. 1995, Hudec et al. 1995, Zouaghi et al. 2013], outpouring of the Thibar Triassic material shows uniform wall of age and therefore it is considered as a simple spreading. The effect of the Atlasic compression is highlighted by the Oligocene angular unconformity on the Paleocene marls showing the gap of the Eocene (Figure 4, Section $\mathrm{BB}^{\prime}$ ).

\section{Conclusions}

Study of the Thibar evaporite structure and neighbouring structures of the Medjerda Valley plain integrates surface and subsurface data to explain salt tectonics of the northern Atlas Mountains of Tunisia.

Based on gravimetric data, the northern part of the Thibar Triassic structure occupies a transitional position between positive and negative anomalies, whereas the southern part of the structure is expressed by a positive anomaly of high amplitude corresponding to the Jebel Mahdi-Jebel Zitoun diapiric outcrop. These results are confirmed by the residual anomalies map. The horizontal gradient and upward continued maps show that the Thibar Triassic body is limited by maxima of horizontal gradient trending NE, indicating the abrupt change of density between the Triassic evaporites and the adjacent strata.

Analysis of seismic sections documents several NWtrending faults, in addition to the NE- trending major structures that delimit highs and asymmetric subsiding lows. At the center of the basin, seismic facies shows outpouring of the Triassic deposits away from the high diapiric structure. The identified geometry highlights a sedimentary instability related to a pre-existent geometry. The blade of Triassic evaporites is overlain by a major unconformity, above which lies Upper Cretaceous and Eocene strata.

The presented study emphasizes how 2D seismic lines and gravity surveys can be employed, integrated, jointly processed and modelled in $2 \mathrm{D}$ to characterize the subsurface in complex Triassic setting. The geophysical model highlights the presences of diapiric structures that produce positive anomalies and are followed by lateral outpouring at the center of the basin.

Our work in the North African Atlas domain consequently suggests the existence of several models for the Triassic evaporites. From this study, we deduce salt pillows represented by high Triassic salifereous associated with Jurassic thickness variations, sealed domes and exposed diapirs during the Lower Cretaceous associated with salt outpouring during the Late Cretaceous and the Paleogene. The Triassic rising is generally controlled by extensional regime; the inverted structures are related to the local or regional compressional stresses recognized at the North African margin.

Acknowledgements. This work was carried out between the CERTE research center and FST Faculty of Sciences. It is a part of a national scientific research project that was financially supported by the Secretariat of Scientific Research and Technology (SERST) of Tunisia. We wish to thank ETAP petroleum society and ONM office of mines for their generous release of geophysical data. The authors sincerely thank Dr. Francesca Bianco, Editor of the journal, for her guidance in the research of this topic, and the anonymous referees for constructive remarks to improve this manuscript.

\section{References}

Abbès, C. (2004). Structurations et évolutions tectonosédimentaires mésozoïques et cénozoïques, associées aux accidents reghmatiques, à la jonction des marges téthysienne et nord-africaine (Chaîne nordsud, Tunisie centrale), Thèse de Doctorat d'Etat, Université de Tunis El Manar, Faculté des Sciences, Tunis (Tunisia), $440 \mathrm{pp}$.

Abdessalem Gharbi, R., L. Chihi, M. Hammami, S. Abdelkader and A. Kadri (2005). Manifestations tectonodiapiriques synsédimentaires et polyphasées d'âge Crétacé supérieur-Quaternaire dans la région de Zag Et Tir (Tunisie centre-nord), C. R. Geosc., 337, 1293-1300.

Adil, S. (1993). Dynamique du Trias dans le nord de la Tunisie: bassins en relais multiples de décrochement, magmatisme et implication minière, Thèse de 3ème cycle, Univ. Tunis el Manar, Fac. Sci. Tunis, 249 pp. Amiri, A., A. Chaqui, I. Hamdi Nasr, N. Ben Ayed and S. Tlig (2011). Role of preexisting faults in the geodynamic evolution of northern Tunisia, insights from gravity data from the Medjerda valley, Tectonophysics, 506, 1-10.

Aridhi, K., M.A. Ould Bagga, S. Abdeljaouad, F. Zargouni and E. Mercier (2011). Lateral ramp-related folding evidences in the Tellian domain of Tunisia: Tectonic implications, C. R. Geosc., 343, 360-369.

Ayed, A., M. Ghanmi, M. Gassmi and M.M. Ben Slama (2006). Apport de la gravimétrie dans la mise en évidence de nouveaux linéaments structuraux dans la région de l'Oued Zarga, massif de Thibar, Tunisie 
septentrionale, 3rd Maghrebin Col. of Applied Geophy. (CMGA3), 167-168.

Ayed-Khaled, A., M. Ghanmi and F. Zargouni (2012). Filtering of the gravimetric anomalies to the study of the geological structures of Oued Zarga (septentrional Tunisia): structural implications, Arab. J. Geosci., 5, 169-180.

Bajanik, S., and J. Salaj (1970). Données nouvelles sur la zone de cicatrice de la région d'Oued Zarga (Tunisie septentrionale), Notes. Serv. Géol., 32, 3-20.

Bajanik, S., and A. Beily (1985). Geological map of Oued Zarga area "scale 1/50,000», Département de Géologie, Office National des Mines, Tunisia.

Bédir, M., S. Tlig, C. Bobier and N. Aissaoui (1996). Sequence Stratigraphy, Basin Dynamics, and Petroleum Geology of the Miocene eastern Tunisia, A.A.P.G. Bull., 80 (1), 63-81.

Bédir, M., N. Boukadi, S. Tlig, F. Ben Timzal, L. Zitouni, R. Alouani, F. Slimane, C. Bobier and F. Zargouni (2001). Subsurface Mesozoic Basins in the central Atlas of Tunisia, tectonics, sequence deposit distribution and hydrocarbon potential, A.A.P.G. Bull., 85, 885-907.

Beily, A., M. Maamouri and Z. Stranik (1982). Geological map of Beja area «scale 1/50,000», Département de Géologie, Office National des Mines, Tunisia.

Ben Assi, R., C. Jallouli, M. Hammami and M.M. Turki (2006). The structure of Jebel El Mourra, Tunisia: a diapiric structure causing a positive gravity anomaly, Terra Nova, 18, 432-439.

Ben Ayed, N. (1986). Evolution tectonique de l'avant pays de la chaine alpine de Tunisie du début du Mésozoique à l'actuel, Thèse Doc. Etat. Univ. Paris Sud, France, $328 \mathrm{pp}$.

Ben Ayed, N. (1993). Évolution tectonique de l'avantpays de la chaîne alpine de Tunisie du début du Mésozoïque à l'Actuel, Ann. Mines Geol., Editions du Serv. Géol. Tunisia, 32, 286 pp.

Ben Chelbi, M., F. Melki and F. Zargouni (2006). Mode de mise en place des corps salifères dans l'Atlas septentrional de Tunisie. Exemple de l'appareil de Bir Afou, C. R. Geosc., 338, 349-358.

Ben Hadj Ali, M., et al. (1994). Geological map of Jendouba area «scale 1/50,000», Département de Géologie, Office National des Mines, Tunisia.

Ben Mehrez, F., J. Kacem and M. Dlala (2009). Late Cretaceous synsedimentary diapirism of Bazina-Sidi Bou Krime Triassic evaporites (northern Tunisia): Geodynamic implications, C. R. Geosc., 341, 78-84.

Ben Slama, M.M., A. Masrouhi, M. Ghanmi, M. Ben Youssef and F. Zargouni (2009). Albian extrusion evidences of the Triassic salt and clues of the beginning of the Eocene atlasic phase from the example of the Chitana-Ed Djebs structure (N. Tunisia): Implication in the North African Tethyan margin recorded events, comparisons, C. R. Geosc., 341, 547-556.

Bismuth, H., C. Boltenhagen, P. Donze, J. Lefèvre and P. Saint Marc (1981). Le Crétacé moyen et supérieur du Jebel Semmama (Tunisie du centre-nord), évolution sédimentologique et microstratigraphique, Cretaceous Res., 3, 171-186.

Blakely, R., and R. Simpson (1986). Approximating edges of sources bodies from magnetic or gravity anomalies, Geophysics, 51, 1494-1498.

Blakely, R.J. (1996). Potential Theory in Gravity and Magnetic Applications, Cambridge University Press.

Bouaziz, S., E. Barrier, M.M. Turki and P. Tricart (1999). La tectonique permo-mésozoique (anté-Vraconien) dans la marge sud téthysienne en Tunisie méridionale, Bull. Soc. Géol. France, 170 (1), 45-56.

Bouaziz, S., E. Barrier, M. Soussi, M.M. Turki and H. Zouari (2002). Tectonic evolution of the northern African margin in Tunisia from paleostress data and sedimentary record, Tectonophysics, 357, 227-253.

Boukadi, N. (1994). Structuration de l'Atlas de Tunisie: Signification géométrique et cinématique des noeuds et des zones d'interférences structurales au contact de grands couloirs tectoniques, Thèse de Doctorat d'Etat. Univ. Tunis El Manar, Fac. Sci. Tunis, 155 pp.

Boukadi, N., and M. Bédir (1996). L'halocinèse en Tunisie: contexte tectonique et chronologique des évènements, C.R. Acad. Sci. Paris, Ser. IIa, 322, 587-594.

Bracène, R., and D. Frizon de Lamotte (2002). The origin of intraplate deformation in the system of western and central Algeria: from Jurassic rifting to Cenozoic-Quaternary inversion, Tectonophysics, 357, 207-226.

Briggs, I. (1974). Machine contouring "using minimum curvature", Geophysics, 39, 39-48.

Burollet, P.F (1956). Contribution à l'étude géologique de la Tunisie centrale, Ann. Mines et Géol., Tunis (18), $352 \mathrm{pp}$.

Chihi, L., and H. Philip (1998). Les fossés de l'extrémité orientale du Maghreb (Tunisie et Algérie orientale): tectonique Mio-Plio-quaternaire et implication dans l'évolution géodynamique récente de la Méditerranée occidentale, Notes Serv. Geol., in Tunisia, 64, 103-116.

Chikhaoui, M., A.L Maamouria, J. Salaj, M.M Turki, J. Saadi, M. Ben Youssef, M. Ghanmi and M. Zarbouta (1998). Tilted blocks during the Early Cretaceous in the Le Kef area (north-western Tunisia), C. R. Acad. Sci. Paris, 327, 265-270.

Chikhaoui, M. (2002). La zone des diapirs en Tunisie: Cadre structural et évolution géodynamique de la 
sédimentation méso-Cénozoïque et géométrie des corps triasiques, Thèse Etat. Géol. Fac. Sci. Tunis, 322 pp.

Cordell, L., and V.J.S. Grauch (1982). Mapping basement magnetization zones from aeromagnetic data, in the San Juan Basin, New Mexico, 52nd Ann. Int. Meet. Soc. Explor. Geophys Dallas. Abstracts and biographies, 246-247.

Daly, K. (1981). Position tectonique du bassin néogène de Jendouba, First. Nat. Cong. of Earth Sci. In Tunisia, 321-331.

Diegel, F.A., D.C. Schuster, R.C. Shoup and P.R. Touvers (1995). Cenozoic structural evolution and tectonostratigraphic framwork of the northern Gulf Coast continental margin, In: M.P.A. Jackson, D.G. Roberts and S. Snelson (eds.), Salt Tectonics, a global perspective, Amer. Assoc. Petrol, Geol., Mem., 65, 109-1151.

Dlala, M. (1995). Seismotectonic study in northern Tunisia, Tectonophys, 209, 171-174.

El Euch, H., M. Saidi, L. Fourati and C. El Mahersi (2004). Northern Tunisia thrust belt: Deformation models and hydrocarbon systems, In: R. Swennen, F. Roure and J.W. Granath (eds.), Deformation, fluid flow, and reservoir appraisal in foreland fold and thrust belts, A.A.P.G. Hedberg Series, 1, 371-390.

El Ouardi, H., and M.M. Turki (1995). Tectonique salifère polyphasée dans la région de Mejez El Bab-Testour "zone des dômes» (Tunisie septentrionale): contrôle de la sédimentation méso-cénozoïque, Géol. Médit., XXVII (2), 73-84.

El Ouardi, H. (2002) Origine des variations latérales des dépôts yprésiens dans la zone des dômes en Tunisie septentrionale, C. R. Geosc., 334, 141-146.

Everaerts, M., and J.L. Mansy (2001). Le filtrage des anomalies gravimétriques; une clé pour la compréhension des structures tectoniques du Bolonais et de l'Artois, Bull. Soc. Geol. France, 3, 267-274.

Frizon de Lamotte, D., P. Leturmy, Y. Missenard, S. Khomsi, G. Ruiz, O. Saddiqi, F. Guillocheau and A. Michard (2009). Mesozoic and Cenozoic vertical movements in the Atlas system (Algeria, Morocco, Tunisia): An overview, Tectonophysics, 475, 9-28.

Ghanmi, M., J.M. Vila, M.Ben Youssef, M. Jouirou and F. Kechrid Ben Khrouf (2000). Le matériel triasique interstratifié dans l'Albien de l'anticlinal autochtone atlasique de Jebel Takrouna (Tunisie): stratigraphie, arguments gravimétriques, signification dans la transversale N-S des confins algéro-tunisiens (Maghreb du Nord-est), Bull. Soc. Hist. Nat. Toulouse, 136, 19-27.

Ghanmi, M., M. Ben Youssef, M. Jouirou, F. Zargouni and J.M Vila (2001). Halocinèse crétacée au Jebel Kebbouch (Nord-Ouest tunisien): mise en place à fleur d'eau et évolution d'un "glacier de sel» albien, comparaisons, Eclog. Geol. Helv., 94, 153-160.

Guiraud, R. (1998). Mesozoic rifting and basin inversion along the northern African Tethyan margin: an overview, In: D.S. Macgregor, R.T.J. Moody and D.D. Clark-Lowes (eds.), Petroleum Geology of North Africa, Geol. Soc., London, Special Publication, 132, 217-229.

Hamdi-Nasr, I., M.H. Inoubli, A. Ben Salem, S. Tlig and A. Mansouri (2009). Gravity contributions to the understanding of salt tectonics from the Jebel Cheid area (dome zone, northern Tunisia), Geophys. Prospect., 57, 719-728.

Hammami, M. (1999). Tectonique, halocinèse et mise en place de la minéralisation dans la zone des diapirs (Tunisie septentrionale), Thèse de Doctorat. Univ. Tunis El Manar, Fac. Sci. Tunis, 213 pp.

Hlaiem, A. (1998). Etude géophysique et géologique des basins et des chaines de Tunisie centrale et méridionale durant le Mésozoique et le Cénozoique, évolution structurale, modélisation géothermique et implications pétrolières, Unpublished $\mathrm{PhD}$ thesis, Université Pierre et Marie Curie - Paris VI (France), $315 \mathrm{pp}$.

Hudec, M.R., R. Fletcher and A. Waltoni (1995). The composites salt glacier: extension on the salt-glacier model to post-burial conditions, A.A.P.G. Annual Convention Official Program (abs.), 45A.

Jacobsen, B.H. (1987). A case for upward continuation as a standard separation filter for potential field maps, Geophysics, 52, 1138-1148.

Jacoby, W., and P.L. Smilde (2009). Gravity Interpretation. Fundamentals and Application of Gravity. Inversion and Geological Interpretation. SpringerVerlag, Berlin Heidelberg.

Jallouli, C., and K. Mickus (2000). Regional gravity analysis of the crustal structure of Tunisia, J. of Afr. Earth Sci., 30, 63-78.

Jauzein, A. (1967). Contribution à l'étude géologique des confins de la dorsale tunisienne (Tunisie septentrionale), Thèse d'État., Ann. Mines Geol., n ${ }^{\circ} 22$, Tunis, $475 \mathrm{pp}$.

Kamoun, F., B. Peybernès, S. Ciszak and S. Calzada (2001). Triassic palaeogeography of Tunisia, Palaeogeogr. Palaeocl., 172, 223-242.

Khattach, D., P. Keating, E.M. Mili, T. Chennouf, P. Andrieux and A. Milhi (2004). Apport de la gravimétrie à l'étude de la structure du bassin des Triffa (Maroc nord-oriental): implications hydrogéologiques, C. R. Géosc., 336, 1427-1432.

Khomsi, S., M. Bédir, M. Soussi, G.M. Ben Jemia, K. and Ben Ismail Lattrache (2006). Mise en évidence en subsurface d'événements compressifs Éocène moyen- 
supérieur en Tunisie orientale (Sahel): généralité de la phase atlasique en Afrique du Nord, C. R. Geosc., 338, 41-49.

Laaridhi-Ouazaâ, N. (1994). Etude minéralogique 514 et géochimique des épisodes magmatiques mésozoïques et miocènes de la Tunisie, Unpublished thesis, Doctorat d'Etat, Université Tunis II, 466 pp.

Masrouhi, A., M. Ghanmi, M.M. Ben Slama, M. Ben Youssef, J.M. Vila and F. Zargouni (2008). New tectono-sedimentary evidence constraining the timing of the positive tectonic inversion and the Eocene Atlasic phase in northern Tunisia: Implication for the North African paleo-margin evolution, C. R. Geosc., 340, 771-778.

Melki, F., T. Zouaghi, M. Ben Chelbi, M. Bédir and F. Zargouni (2010). Tectono-sedimentary events and geodynamic evolution of the Mesozoic and Cenozoic basins of the Alpine Margin, Gulf of Tunis, north-eastern Tunisia offshore, C. R. Géosc., 342, 741-753.

Melki, F., T. Zouaghi, S. Harrab, A. Casas Sainz, M. Bédir and F. Zargouni (2011). Structuring and evolution of Neogene trascurrent basins in the Tellian foreland domain, north-eastern Tunisia, J. Geodyn., 52, 57-69.

Mzali, H., and H. Zouari (2006). Caractérisation géométrique et cinématique des structures liées aux phases compressives de l'Éocène au Quaternaire inférieur en Tunisie: exemple de la Tunisie nord-orientale, C. R. Geosc., 338, 742-749.

Ould Bagga, M.A., S. Abdeljaouad and E. Mercier (2006). La «zone des nappes» de Tunisie: une marge mésocénozoïque en blocs basculés modérément inversée (région de Tabarka/Jendouba; Tunisie nord-occidentale), Bull. Soc. Géol. France, 177 (3), 145-154.

Perthuisot, V. (1978). Dynamique et pétrogenèse des extrusions triasiques en Tunisie septentrionale, Thèse d’État, École Normale Supérieure, ERA 604-CNRS, $321 \mathrm{pp}$.

Perthuisot, V. (1979). Geological map of Teboursouk area «scale 1/50,000», Département de Géologie, Office National des Mines, Tunisia.

Rouvier, H. (1977). Géologie de l'extrême Nord tunisien: tectonique et paléogéographie superposées à l'extrême orientale de la chaîne nord maghrébine, Thèse es Sciences, Université de Paris VI, 898 pp.

Rouvier, H. (1995). Geological map of Bou Salem area «scale 1/50,000», Département de Géologie, Office National des Mines, Tunisia.

Solignac, M. (1927). Etude géologique de la Tunisie septentrionale, Thèse, Lyon.Dir.Trav. Pub., carte géol. Tunisie, 756 pp.

Soussi, M. (2003). Nouvelle nomenclature lithostrati- graphique «évènementielle» pour le Jurassique de la Tunisie atlasique, Geobios, 36, 761-773.

Turki, M.M. (1985). Polycinématique et contrôle sédimentaire associé sur la cicatrice Zaghouan-Nebhana, Thèse Doc.Etat, Univ. Tunis et Revue Sc. Terre, C.S.T-I.N.R.S.T (éd.), 7, 228 pp.

Vanié, L.T.A., D. Khattach and M.R Houari (2005). Apport des filtrages des anomalies gravimétriques à l'étude des structures profondes du Maroc oriental, Bull. Inst. Sci. Rabat, Section Sci. de la Terre, 27, 29-40.

Vila, J.M., M. Ben Youssef, A. Charrière, M. Chikhaoui, M. Ghanmi, F. Kammoun, B. Peybernès, J. Saadi, P. Souquet and M. Zarbout (1994). Découverte en Tunisie au SW du Kef de matériel triasique interstratifié dans l'Albien: extension du domaine à "glacier de sel» sous-marin des confins algéro-tunisiens, C. R. Acad. Sci. Paris, Ser. II, 318, 109-116.

Vila, J.M. (1995). Halocinèse distensive albienne à «glaciers de sel» sous-marins et plissement tertiaire du secteur Ouenza-Ladjebel-Meridef: précisions à la suite de l'article d'A. Bouzenoune, H. Rouvier et J. Thibiéroz, «Trias de l'Ouenza: contexte diapirique, zonation minéralogique et conséquences métallogéniques», Bull. Serv. Géol. (Algéria), 2, 1-35.

Wu, S., A. Bally and C. Cramez (1990). Allochtonous salt, structure and stratigraphy of the northeastern Gulf of Mexico, Part 11: Structure, Mar. Petrol. Geol., 7, 334-370.

Zargouni, F. (1977). Etude structurale de la bande triasique de Baouala- Aroussia-El Mecherket (Zone de diapirs, Atlas tunisien), Bull. Soc. Sc. Nat. Tunis., 12, 79-82.

Zouaghi, T., M. Bédir and M.H. Inoubli (2005). 2D Seismic interpretation of strike-slip faulting, salt tectonics, and Cretaceous unconformities, Atlas Mountains, central Tunisia, J. Afr. Earth Sci., 43, 464-486.

Zouaghi, T., M. Bédir, F. Melki, H. Gabtni, R. Gharsalli, A. Bessioud and F. Zargouni (2011). Neogene sediment deformations and tectonic features of northeastern Tunisia: evidence for paleoseismicity, Arab. J. Geosc., 4, 1301-1314.

Zouaghi, T., M. Bédir, A. Ayed-Khaled, M. Lazzez, M. Soua, A. Amri and M.H. Inoubli (2013). Autochthonous versus allochthonous Upper Triassic evaporites in the Sbiba graben, central Tunisia, J. Struct. Geol., 52, 163-182.

Corresponding author: Amira Ayed-Khaled, Université Tunis El Manar, Département de Géologie, Tunis, Tunisia; email: ammoura.khaled@gmail.com.

(C) 2015 by the Istituto Nazionale di Geofisica e Vulcanologia. All rights reserved. 